\title{
EML4/ALK Fusion Protein Variant 3b
}

National Cancer Institute

\section{Source}

National Cancer Institute. EML4/ALK Fusion Protein Variant 3b. NCI Thesaurus. Code C99737.

A fusion protein (796 aa, $88 \mathrm{kDa}$ ) that is encoded by the EML4/ALK variant 3b fusion gene. This protein contains the amino acids encoded by exons 1-6b of the echinoderm microtubule-associated protein-like 4 and the entire cytoplasmic region of the ALK tyrosine kinase receptor protein including the tyrosine kinase domain. 